\section{Gategory}

Polymer-Supported Synthesis

\section{Key words}

heteropoly acids

intermolecular hydroamination

amides

olefins

SYNFACTuth
of the moluth

L. YANG, L.-W. XU,* C.-G. XIA* (LANZHOU INSTITUTE OF CHEMICAL PHYSICS, P. R. OF CHINA AND NATIONAL UNIVERSITY OF SINGAPORE, SINGAPORE)

Heteropoly Acids: A Green and Efficient Heterogeneous Brønsted Acidic Catalyst for the Intermolecular Hydroamination of Olefins

Tetrahedron Lett. 2008, 49, 2882-2885.

\title{
Heteropoly Acid Catalyzed Hydroamination of Alkenes
}

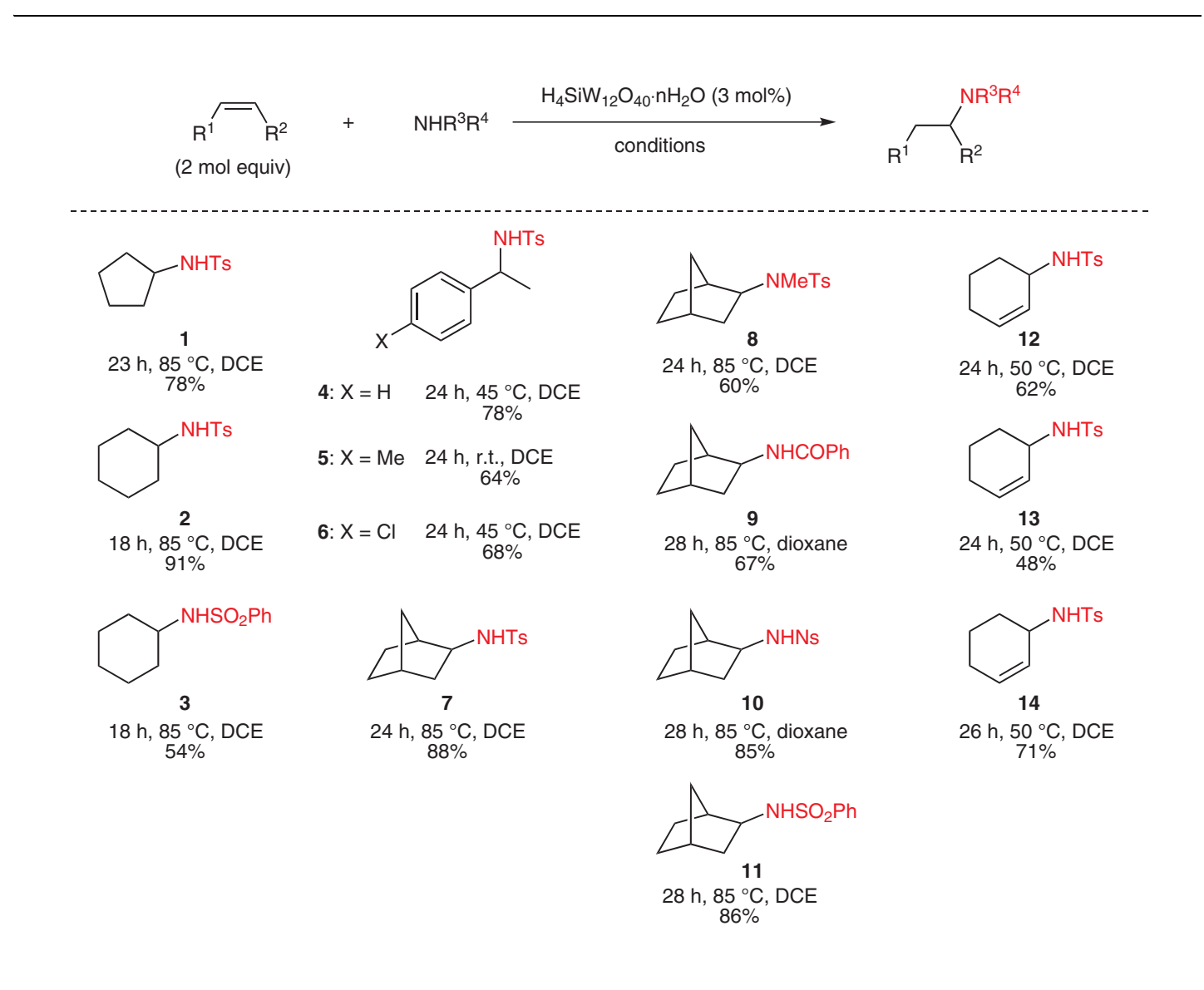

Significance: Heteropoly acids (HPAs) catalyzed hydroamination of alkenes was described. Thus, the intermolecular hydroamination of alkenes (2 mol equiv) with amides or carbamates was performed in the presence of $\mathrm{H}_{4} \mathrm{SiW}_{12} \mathrm{O}_{40} \mathrm{nH}_{2} \mathrm{O}$ (3 mol\%) in dichloroethane (DCE) at r.t. to $85^{\circ} \mathrm{C}$ to afford the corresponding products 1-14 in 48$91 \%$ isolated yield. The catalyst was reused twice with slight loss of catalytic activity $\left(1^{\text {st }}\right.$ use $=78 \%$, $2^{\text {nd }}$ use $=74 \%, 3^{\text {rd }}$ use $=62 \%$ ).
Comment: $\mathrm{H}_{4} \mathrm{SiW}_{12} \mathrm{O}_{40} \mathrm{nH}_{2} \mathrm{O}$ was the most efficient HPAs catalyst (2: 95\%) compared with $\mathrm{H}_{3} \mathrm{PW}_{12} \mathrm{O}_{40} \mathrm{nH}_{2} \mathrm{O}(\mathbf{2}: 63 \%), \mathrm{H}_{3} \mathrm{PMO}_{12} \mathrm{O}_{40} \mathrm{nH}_{2} \mathrm{O}$ (2: $82 \%), \mathrm{Na}_{3} \mathrm{PMo}_{12} \mathrm{O}_{40}$ (no reaction), $\left(\mathrm{NH}_{4}\right)_{3} \mathrm{PW}_{12} \mathrm{O}_{40}$ (2: trace) and $\mathrm{Ag}_{3} \mathrm{PW}_{12} \mathrm{O}_{40}$ (2: trace). The catalyst was recycled via simple filtration and washing with DCE. 